\title{
Nivolumab induced myxedema crisis
}

\author{
Uqba Khan* (i), Humaira Rizvi, Dahlia Sano, Jane Chiu and Tarik Hadid
}

\begin{abstract}
Background: Nivolumab is an anti-programmed cell death (anti-PD-1) monoclonal antibody that is approved by Food and Drug Administration for treatment of metastatic non-small cell lung cancer, metastatic melanoma, relapsed Hodgkin lymphoma and advanced renal cell cancer. We report a rare case of myxedema crisis induced by nivolumab in a patient with metastatic squamous cell carcinoma of lung.

Case presentation: Fifty three-year old woman with metastatic squamous cell carcinoma currently on treatment with nivolumab presented with diffuse facial and tongue swelling, slurred speech, depressed mentation, fatigue and weakness. Initial evaluation revealed severe hypothyroidism with thyroid stimulating hormone of 237 micro Unit/mL (Normal Reference range: 0.27-4.20 micro unit $/ \mathrm{mL}$ ) and undetectable free T4. Patient was diagnosed with nivolumab induced myxedema crisis. She was treated successfully with levothyroxine with complete resolution of her symptoms. Nivolumab was safely restarted once the symptoms of myxedema resolved.

Conclusion: Nivolumab can cause immune-mediated endocrinopathies including thyroiditis, hypophysitis, adrenal insufficiency and type 1 diabetes mellitus. High index of suspicion and periodic measurement of thyroid function tests are recommended in patients receiving nivolumab therapy. Our case also suggests that once the myxedema crisis is treated and symptoms are resolved, nivolumab can be safely re-challenged.
\end{abstract}

Keywords: Nivolumab, Immunotherapy, Myxedema crisis, Hyperthyroidism

\section{Background}

Cancer treatment has rapidly advanced over the recent years with exodus of newly approved therapies for various malignancies. Immunomodulatory agents such as nivolumab have a unique mechanism of action, dramatically different from that of traditional chemotherapy. As a result, toxic effects are also unique and predominantly immune mediated. Nivolumab is one example of immunotherapy drugs, which is approved by Food and Drug Administration for treatment of metastatic non-small cell lung cancer, metastatic melanoma, relapsed Hodgkin's lymphoma, metastatic head and neck cancer and advanced renal cell cancer. Although a number of immune mediated adverse effects of nivolumab are reported but myxedema is a very rare adverse effect [1]. Herein, we present a rare case of nivolumab-mediated myxedema in a patient with nonsmall cell lung cancer (NSCLC).

\footnotetext{
*Correspondence: uqba.md@gmail.com

Department of Hematology/Oncology, St. John Hospital and Medical Center, 19229 Mack Ave Suite 23 Grosse Pointe Woods, Detroit 48236, Michigan, USA
}

(c) The Author(s). 2017 Open Access This article is distributed under the terms of the Creative Commons Attribution 4.0 International License (http://creativecommons.org/licenses/by/4.0/), which permits unrestricted use, distribution, and reproduction in any medium, provided you give appropriate credit to the original author(s) and the source, provide a link to the Creative Commons license, and indicate if changes were made. The Creative Commons Public Domain Dedication waiver (http://creativecommons.org/publicdomain/zero/1.0/) applies to the data made available in this article, unless otherwise stated.

\section{Case presentation}

A 53-year-old woman was diagnosed with metastatic squamous cell carcinoma of lung with involvement of the liver and mediastinal lymph nodes. She has a history of hypertension, chronic kidney disease due to prior cisplatin use and uterine fibroids but no history of thyroid disease or any other autoimmune disorders. She was receiving second-line therapy using nivolumab, to which she achieved excellent response and complete resolution of liver disease and significant response in the lung and mediastinal lesions. Programmed death-ligands 1 (PD-L1) were expressed on $81-90 \%$ of malignant cells. She was doing well until she presented to the emergency department with slurred speech, progressive diffuse facial, periorbital swelling and tongue swelling over the last few weeks. She also complained of generalized weakness, fatigue, forgetfulness, constipation, dyspnea, slow voice, cold intolerance and dry skin. Physical examination revealed slightly overweight woman with cushinoid appearance, depressed mentation, poor memory and delayed relaxation phase of deep tendon reflexes. Facial examination revealed diffuse facial, periorbital and neck swelling. She 
has no thyromegaly or lymphadenopathy. The rest of the examination was unremarkable.

Laboratory findings showed hemoglobin of $87 \mathrm{gm} / \mathrm{L}$, mean corpuscular volume of $94 \mathrm{fL}$, white blood cell count of $4.6 \times 10^{9} / \mathrm{L}$, platelets of $238 \times 10^{9} / \mathrm{L}$, creatinine of $209.5 \mu \mathrm{mol} / \mathrm{L}$, sodium of $136 \mathrm{mmol} / \mathrm{L}$, potassium of $4.4 \mathrm{mmol} / \mathrm{L}$ and calcium of $2.5 \mathrm{mmol} / \mathrm{L}$. Thyroid function tests revealed thyroid-stimulating hormone of 237 micro Unit $/ \mathrm{mL}$ and free T4 $1 \mathrm{pmol} / \mathrm{L}$. Cortisol level was $303 \mathrm{nmol} / \mathrm{L}$. Creatine kinase was elevated at $23.80 \mu \mathrm{kat} / \mathrm{L}$ suggestive of myopathy due to severe hypothyroidism. Computed tomography of the brain revealed no evidence of intracranial metastasis.

These clinical and laboratory findings were consistent with myxedema crisis. Therefore, she was hospitalized and immediately initiated on $100 \mu \mathrm{g}$ of intravenous (IV) levothyroxine for 3 days. This was followed by $137 \mu \mathrm{g}$ of oral levothyroxine daily. In addition, she was started on IV hydrocortisone which was subsequently discontinued once adrenal insufficiency was ruled out. She expressed dramatic recovery of her symptoms and laboratory studies. Nivolumab was suspected to be the culprit of myxedema in this patient and was held until symptoms improved. She was subsequently restarted on nivolumab without recurrent symptoms. On continued follow up, she was given another 10 cycles of nivolumab over 5 months period without any signs or symptoms of myxedema.

\section{Discussion and conclusions}

Cancer treatment has revolutionized in recent years. Development of new therapies especially immunotherapy has greatly impacted the outcome of malignant disorders. However, the toxic effects associated with these agents are dramatically different from those encountered with chemotherapy.

There are various immune checkpoints pathways exist which limit the immune response of the body to reduce autoimmunity. One such pathway is programmed cell death pathway (PD-1), which acts as a checkpoint to reduce T-cell mediated immune responses [2, 3]. PDL-1, which are present on tumor, attach with the PD1 receptors on Tlymphocyte and induce signals causing reversible inhibition of $\mathrm{T}$ cell activation and proliferation [2]. By blocking this interaction of PDL-1 with PD-1, immune response can be mounted against malignant cells.

Nivolumab is an anti-programmed cell death (anti-PD1) monoclonal antibody. The Food and Drug Administration (FDA) approved this agent for treatment of metastatic non-small cell carcinoma, metastatic melanoma, relapsed Hodgkin's lymphoma, metastatic head and neck cancer and advanced renal cell carcinoma [4]. Nivolumab is a well-tolerated agent with the most common side effects being fatigue, musculoskeletal pain, decreased appetite, cough, and constipation. Nivolumab is also associated with several immune-mediated toxic effects such as colitis, pneumonitis, hepatitis, nephritis, skin-rash and endocrine glands dysfunction. Immune-mediated endocrinopathies include thyroiditis, hypophysitis, adrenal insufficiency and type 1 diabetes mellitus.

Thyroid dysfunction is seen infrequently in patients receiving nivolumab. Both hyperthyroidism and hypothyroidism can occur in patients receiving nivolumab. In clinical trials, grade 1 and 2 hyperthyroidism occurred in 1.4-4.4\% of patients receiving nivolumab [5-7]. Grade 3 hyperthyroidism is reported in one patient with metastatic melanoma receiving nivolumab [8-10]. The median time to its occurrence was about 2-3 months [11]. Grade 1 and 2 hypothyroidism is estimated to occur in $7-9 \%$ of patients receiving nivolumab [5-7]. Grade 3 hypothyroidism was reported in 3 patients, one with metastatic melanoma and two with renal cell carcinoma [11, 12]. The median time to development of hypothyroidism was 2.9 months. It is recommended to check TSH and free T4 before each treatment.

Management of nivolumab-induced hypothyroidism depends on severity of the disease. If hypothyroidism is mild, simple replacement of levothyroxine is sufficient. If hypothyroidism is moderate or severe as in our case, management often requires multidisciplinary approach to avoid life-threatening cardiac complications associated with levothyroxine replacement. It is recommended to hold nivolumab in patients with severe hypothyroidism but it can be reinstituted once the patient is stabilized, as in our patient.

Checkpoint inhibitors especially nivolumab have revolutionized the treatment of various hematological and solid malignancies. It is not only important for oncologists but as well as for general practitioners to be familiarize with unusual adverse effects of these drugs. Immune mediated thyroid dysfunction remains an important adverse effect of checkpoint inhibitors. It has become our routine practice to check baseline thyroid function tests and monitor them periodically during the nivolumab treatment. It is recommended to check TSH and free T4 before every cycle of nivolumab.

\section{Abbreviations \\ FDA: Food and drug administration; gm/L: Gram/liter; ml: Millilitler; mmol/ L: Millimole/liter; NSCLC: Non-small cell lung cancer; PD-1: Programmed cell death 1; PD-L1: Programmed death-ligands 1; pmol/L: Picomole/liter; $\mu \mathrm{g}$ : Microgram; $\mu \mathrm{kat} / \mathrm{L}$ : Micro katal/liter; $\mu \mathrm{mol} / \mathrm{L}$ : Micromole/liter}

\section{Acknowledgement}

None.

\section{Funding}

No funding was required for the case report.

Availability of data and material

Not applicable. 


\section{Authors' contribution}

UK and HR wrote the manuscript. TH and JC primarily took care of patient.

DS proof- read the manuscript. All authors approved the manuscript.

\section{Competing interests}

The authors declare that they have no competing interests.

\section{Consent for publication}

Informed written consent was obtained from patient for publication of this case. Consent is available on request.

\section{Ethics approval and consent to participate}

Not applicable.

Received: 30 September 2016 Accepted: 23 January 2017

Published online: 21 February 2017

\section{References}

1. Tanaka R, Fujisawa Y, Maruyama H, Nakamura Y, Yoshino K, Ohtsuka M, Fujimoto M. Nivolumab-induced thyroid dysfunction. Jpn J Clin Oncol. 2016; 46(6):575-9. doi:10.1093/jjco/hyw036. Epub 2016 Mar 23.

2. Keir ME, Butte MJ, Freeman GJ, Sharpe AH. PD-1 and its ligands in tolerance and immunity. Annu Rev Immunol. 2008;26:677-704. doi:10.1146/annurev. immunol.26.021607.090331.

3. Ansell SM, Lesokhin AM, Borrello I, Halwani A, Scott EC, Gutierrez M, et al. PD-1 blockade with nivolumab in relapsed or refractory Hodgkin's lymphoma. N Engl J Med. 2015;372(4):311-9. doi:10.1056/NEJMoa1411087. Epub 2014 Dec 6.

4. United States food and drug administration. Hematology/Oncology (Cancer) Approvals \& Safety Notifications. http://www.fda.gov/Drugs/ InformationOnDrugs/ApprovedDrugs/ucm279174.htm. Accessed 1 Jan 2017.

5. Borghaei H, Paz-Ares L, Horn L, Spigel DR, Steins M, Ready NE, et al. Nivolumab versus docetaxel in advanced non-squamous Non-small-cell lung cancer. N Engl J Med. 2015;373(17):1627-39. doi:10.1056/ NEJMoa1507643. Epub 2015 Sep 27.

6. Brahmer J, Reckamp KL, Baas P, Crinò L, Eberhardt WE, Poddubskaya E, et al. Nivolumab versus docetaxel in advanced squamous-cell non-small-cell lung cancer. N Engl J Med. 2015;373(2):123-35. doi:10.1056/NEJMoa1504627. Epub 2015 May 31.

7. Larkin J, Chiarion-Sileni V, Gonzalez R, Grob JJ, Cowey CL, Lao CD, et al. Combined nivolumab and ipilimumab or monotherapy in untreated melanoma. N Engl J Med. 2015;373(1):23-34. doi:10.1056/NEJMoa1504030. Epub 2015 May 31

8. Weber JS, D'Angelo SP, Minor D, Hodi FS, Gutzmer R, Neyns B, et al. Nivolumab versus chemotherapy in patients with advanced melanoma who progressed after anti-CTLA-4 treatment (CheckMate 037): a randomized, controlled, open-label, phase 3 trial. Lancet Oncol. 2015;16(4):375-84. doi:10. 1016/S1470-2045(15)70076-8. Epub 2015 Mar 18.

9. Larkin J, Chiarion-Sileni V, Gonzalez R, Grob JJ, Cowey CL, Lao CD, et al. Combined nivolumab and ipilimumab or monotherapy in untreated melanoma. N Engl J Med. 2015;373(1):23-34. doi:10.1056/NEJMoa1504030. pub 2015 May 31

10. Robert C, Long GV, Brady B, Dutriaux C, Maio M, Mortier L, et al. Nivolumab in previously untreated melanoma without BRAF mutation. N Engl J Med. 2015:372(4):320-30. doi:10.1056/NEJMoa1412082. Epub 2014 Nov 16.

11. Opdivo prescribing information. http://packageinserts.bms.com/pi/pi_ opdivo.pdf. Accessed 1 Jan 2017.

12. Motzer RJ, Escudier B, McDermott DF, George S, Hammers HJ, Srinivas S, et al. Nivolumab versus everolimus in advanced renal-cell carcinoma. N Engl J Med. 2015;373(19):1803-13. doi:10.1056/NEJMoa1510665. Epub 2015 Sep 25.

\section{Submit your next manuscript to BioMed Central and we will help you at every step:}

- We accept pre-submission inquiries

- Our selector tool helps you to find the most relevant journal

- We provide round the clock customer support

- Convenient online submission

- Thorough peer review

- Inclusion in PubMed and all major indexing services

- Maximum visibility for your research

Submit your manuscript at www.biomedcentral.com/submit 